\title{
Legume Wafer Supplementation to Increase the Performance of Post-Weaning Ettawa Grade Goats
}

\author{
B. D. Dianingtyas ${ }^{a}$, Y. Retnani ${ }^{b, *}$, \& D. Evvyernie ${ }^{b}$ \\ aStudy Program of Nutrition and Feed Science, Faculty of Animal Science, Postgraduate School, \\ Bogor Agricultural University \\ ${ }^{b}$ Department of Nutrition and Feed Technology, Faculty of Animal Science, Bogor Agricultural University \\ Jalan Agatis, Kampus IPB Darmaga Bogor 16680, Indonesia \\ (Received 08-12-2016; Reviewed 25-01-2017; Accepted 10-04-2017)
}

\begin{abstract}
This research was conducted to analyze the effect of legume wafer supplementation on the performance of post weaning Ettawa Grade goats. A total of 16 post weaning Ettawa Grade goats (average body weight $13.10 \pm 0.91 \mathrm{~kg}$ ) were grouped into 4 group treatments and 4 blocks as replicate in a completely randomized block design. The treatments were T0 (basal diet/control), T1 (supplementation of $12.12 \%$ wafer supplement of Indigofera zollingeriana), T2 (supplementation of $13.54 \%$ wafer supplement of Leucaena leucocephala) and T3 (supplementation of $12.37 \%$ wafer supplement of Calliandra calothyrsus). The feed intake, nutrient digestibility, average daily gain (ADG), feed efficiency (FE), and income over feed cost (IOFC) were observed. The results showed that supplementation of legume wafer increased $(\mathrm{P}<0.05)$ the feed intake, organic matter digestibility, ADG, FE, and IOFC. Supplementation of I. zollingeriana wafer increased ADG by $55.08 \%$, FE by $34.91 \%$, and IOFC by $14.53 \%$; L. leucocephala wafer increased ADG by $66.18 \%$, FE by $41.63 \%$, and IOFC by $19.09 \%$; and C. calothyrsus wafer increased ADG by $32.62 \%$, FE by $11.30 \%$, and IOFC by $14.34 \%$. In conclusion, the addition of legume wafer supplements into the rations could increase the feed utility value of legumes and L. leucocephala wafer at $13.54 \%$ showed the best performance in post-weaning Ettawa Grade goats.
\end{abstract}

Keywords: post-weaning Ettawa Grade goats, legumes wafer, indigofera, Leucaena leucocephala, Calliandra calothyrsus

\begin{abstract}
ABSTRAK
Penelitian ini bertujuan untuk mengevaluasi dan mencari pemberian suplemen wafer leguminosa terbaik dalam meningkatkan kinerja kambing Peranakan Etawah (PE) lepas sapih. Rancangan percobaan yang digunakan adalah rancangan acak kelompok dengan 4 perlakuan dan 4 kelompok sebagai ulangan dengan menggunakan 16 kambing PE lepas sapih dengan rerata bobot badan $13.10 \pm 0.91 \mathrm{~kg}$. Perlakuan terdiri atas P0 (ransum basal), P1 (suplementasi $12.12 \%$ wafer Indigofera zollingeriana), P2 (suplementasi 13.54\% wafer lamtoro/Leucaena leucochepala), P3 (suplementasi 12.37\% wafer kaliandra/Caliandra calotyrsus). Variabel yang diukur meliputi: konsumsi pakan, kecernaan pakan, pertambahan bobot badan harian (PBBH), efisiensi penggunaan pakan (EPP), serta income over feed cost (IOFC). Hasil penelitian menunjukkan bahwa pemberian suplemen wafer leguminosa pada kambing PE lepas sapih meningkatkan $(\mathbf{P}<0.05)$ konsumsi pakan, kecernaan bahan organik, PBBH, EPP, serta IOFC dibandingkan kambing PE lepas sapih yang tidak diberi suplemen wafer leguminosa. Pemberian suplemen wafer I. zollingeriana dapat meningkatkan $55.08 \%$ PBBH, $34.91 \%$ EPP, dan $14.53 \%$ IOFC; wafer lamtoro dapat meningkatkan $66.18 \%$ PBBH, $41.63 \%$ EPP, dan $19.09 \%$ IOFC; dan wafer kaliandra dapat meningkatkan $32.62 \%$ PBBH, $11.30 \%$ EPP, dan $14.34 \%$ IOFC. Kesimpulan dari penelitian ini adalah pemanfaatan leguminosa sebagai wafer suplemen pakan di dalam ransum mampu meningkatkan nilai guna ransum dan wafer $L$. leucocephala pada taraf $13.54 \%$ menunjukkan performa terbaik pada kambing PE lepas sapih.
\end{abstract}

Key words: kambing Peranakan Etawah lepas sapih, wafer leguminosa, indigofera, Leucaena leucocephala, Calliandra calothyrsus

${ }^{*}$ Corresponding author:

E-mail: yuli.retnani@yahoo.com 


\section{INTRODUCTION}

Indonesian milk consumption, at around 11.09 liters per capita per year, is still considered low compared to that of other ASEAN countries (Association of South East Asian Nations), which is around 20 liters per capita per year (Kemenperin 2014). The dairy products consumed are mostly of bovine milk origin. Smaller ruminants such as dairy goats contribute to smaller extend. One of dairy goats that are potential to produce milk is Ettawa Grade goat. Ettawa Grade goat is a cross between Etawah goat (India) and Kacang goat (Indonesia) and has appearance of Ettawa goat with smaller body frame. Ettawa Grade goat can produce both milk and meat. Their beneficial characteristics are easy maintenance, faster reproduction compared to dairy cattle, and are prolific (can give birth to more than one offspring in one gestation).

The growing phase of post weaning goats is the initial phase to early determine their potential productivity as dairy goat or for breeding. Mellado et al. (2011) argued that this phase greatly influences the productivity of dairy goats, i.e. the milk production volume and the profit earned by farmers. Efforts have been made to improve the growing phase of post weaning goats. One of them is by improving the feed quality.

The productivity of ruminant livestock is largely determined by the availability as well as the affordability of high-quality forage all year round. In reality, breeders are often forced to give low quality feed due to the limited availability of forage, so consequently feeding are often below standart requirement. Therefore, high-quality feed supplement is needed to overcome the shortage of such things in order to increase the productivty of livestock. One of the way, legumes as a supplement in the bredeer rations. In this matter, legumes can be used as additional protein source.

Legumes make a potential protein source for animal feed for its high protein content. Among many types of legumes, Indigofera zollingeriana, Leucaena leucocephala and Calliandra calothyrsus can be used as alternative forage. It was reported that I. zollingeriana contains 23.1\% protein (Ali et al., 2014), L. leucocephala has 15\%$38 \%$ protein (Zayed et al., 2014), while C. calothyrsus leaves have $19.3 \%$ protein (Stürm et al., 2007).

However, utilization of legumes as feed is limited by some drawbacks, i.e. its seasonal availability, perishability, and voluminosity. Hence, processing is needed to overcome this limitation, for example by converting it into wafers. Wafer feed is an example of feed preservation technology that not only prolongs legume's shelf life, but also reduces its volume and thus eases the handling, storage, distribution, and feeding. Wafer feed must contain enough energy, minerals, vitamins, and protein needed by the animals to increase their productivity. This supplement is the result of the utilization of feed processing technology to improve the feed value (Retnani et al., 2010). This research was conducted to evaluate the effect and to find the best of legume wafer supplementation that enhance the performance of post weaning Ettawa Grade goats.

\section{MATERIALS AND METHODS}

\section{Materials}

Sixteen post-weaning Ettawa Grade female goats, aged about 4 months with average body weight of $13.10 \pm 0.91 \mathrm{~kg}$, were kept in individual cages. They were grouped into four feeding treatments, each has 4 animals as replicate. The legume wafer supplement was composed of legumes (I. zollingeriana, L. leucocephala, and $C$. calothyrsus), molasses, and lime. The processing of legume wafer supplement included chopping, drying, mixing, pressing, heating and forming at temperature of $100^{\circ} \mathrm{C}$ for $10 \mathrm{~min}$, followed by cooling at room temperature (Retnani et al., 2014).

Basal diet (T0) consisted of forage and concentrate including soybean husk with ratio of $35: 65$. The legume wafer was supplemented based on the deficiency of crude protein in Cordero Farm's basal diet. Legume wafer was supplemented at $12.12 \%, 13.54 \%$, and $12.37 \%$ from total dry matter intake for I. zollingeriana, L. leucocephala, and C. calothyrsus, respectively. The nutrient composition for each treatment is presented in Table 1.

\section{Feeding Management}

The ration was calculated based on daily requirement (3.5\% of body weight). The goats were fed with legume wafer at 07.00 WIB, followed by concentrate at $08.00 \mathrm{WIB}$, and forage at $16.00 \mathrm{WIB}$.

\section{Data Collection}

The experiment was conducted in individual cages at Cordero Farm, Ciapus, Bogor. The feed and feces

Table 1. Nutrient composition of treatments

\begin{tabular}{lcccc}
\hline \multirow{2}{*}{ Ration } & \multicolumn{3}{c}{$\begin{array}{c}\text { Composition of basal diet + legume } \\
\text { wafer supplement (\%) }\end{array}$} \\
\cline { 2 - 5 } & T0 & T1 & T2 & T3 \\
\hline Forage & 35 & 30.76 & 30.26 & 30.67 \\
Concentrate & 65 & 57.12 & 56.20 & 56.96 \\
Wafer of Indigofera & 0 & 12.12 & 0 & 0 \\
zollingeriana & & & & \\
Wafer of Leucaena & 0 & 0 & 13.54 & 0 \\
leucocephala & & & & \\
Wafer of Calliandra & 0 & 0 & 0 & 12.37 \\
calothyrsus & & & & \\
Nutrient & & & & \\
$\quad$ Ash & 8.10 & 7.92 & 8.32 & 8.36 \\
$\quad$ Ether extract & 4.88 & 4.59 & 4.65 & 5.13 \\
Crude protein & 12.86 & 14.40 & 14.16 & 14.36 \\
Crude fiber & 26.10 & 24.80 & 24.70 & 24.28 \\
$\quad$ Nitrogen-free extract & 48.07 & 48.29 & 48.17 & 47.88 \\
Total digestible & 61.01 & 61.82 & 61.61 & 62.12 \\
nutrien & & & & \\
\hline
\end{tabular}

Note: $\mathrm{T} 0=$ Basal diet $/$ control; $\mathrm{T} 1=\mathrm{T} 0+12.12 \%$ wafer of Indigofera zollingeriana; $\mathrm{T} 2=\mathrm{T} 0+13.54 \%$ wafer of Leucaena leucocephala; $\mathrm{T} 3=\mathrm{T} 0+$ $12.37 \%$ wafer of Calliandra calothyrsus. 
were analyzed at Laboratory of Inter University Centre. Legume wafer was produced at Laboratory of Feed Industry, Faculty of Animal Science, Bogor Agricultural University. The experiment consisted of 3 periods i.e., preliminary, growth, and collection. Preliminary period aimed to remove the residues from previous feed consumed by the post-weaning Ettawa Grade goats and was conducted for $14 \mathrm{~d}$. In growth period, the goats were weighted once every 2 weeks during 68 d. This period was designed to study the effect of the treatments on the body weight gain. Collection period was designed to record and measure the digestibility of nutrients. For 1 week, the feces and feed samples were collected daily. The weight of the feces as well as the feed intake were recorded, $10 \%$ from total feces was collected for analysis.

\section{Procedures for variable measurement}

Dry matter intake. Dry matter intake (kg/day) was calculated by multiplying fresh feed weight with dry matter content of the ration, subtracted with dry matter of the unconsumed feed.

Nutrient digestibility. Nutrient digestibility was calculated by subtracting nutrient intake with nutrient of the feces, the result was divided by the total nutrient intake and multiplied by 100\% (Pond et al., 2005). nutrient intake was based on proximate analysis and the nutrient of the feces was the average of that during the last week of experimental period. The nutrient digestibility was calculated as follow:

Nutrient digestibility $\%=[($ nutrient intake - nutrient of feces)/ nutrient intake] x $100 \%$

Body weight gain. Body weight gain is the difference of the body weight at the beginning and at the end of experiment (Imran et al., 2012).

Feed efficiency. Feed efficiency was the body weight gain divided by total feed intake during the experiment multiplied by $100 \%$ (Campbell et al., 2006).

Income over feed cost (IOFC). IOFC was calculated by subtracting selling price multiplied body weight gain, and feed cost (Mayulu et al., 2009).

$\mathrm{IOFC}=($ selling price $\mathrm{x}$ body weight gain $)-$ feed cost

\section{Data Analysis}

The experimental design used was completely randomized block design with 4 treatments and 4 blocks. The treatments were: T0 (basal diet/control), T1 (T0 + $12.12 \%$ wafer supplement of $I$. zollingeriana), T2 (T0+ $13.54 \%$ wafer supplement of L. leucocephala) and T3 (T0 $+12.37 \%$ wafer supplement of C. calothyrsus). Data were analyzed with ANOVA and the differences among treatments were examined with Duncan test (Steel \& Torrie, 1995).

\section{RESULTS}

Tabel 1 showed the composition and nutrient content of the ration. Each wafer supplement was added to the ration at different percentage due to differences in nutrient contents. The crude protein and total digestible nutrient (TDN) of I. zollingeriana wafer (T1), L. leucocephala wafer (T2), and C. calothyrsus wafer (T3) were higher than control (T0), by around $27.37 \%$ and $17 \%$, respectively.

The nutrient intake, digestibility, average body weight, feed efficiency, and IOFC are presented in Table 2. Analysis of variance (ANOVA) showed that except for crude fiber and organic matter digestibility, all nutrient intake parameters, final body weight, ADG, feed efficiency, and IOFC of wafer supplement treatments (T1, T2, T3) were all higher than those of control (T0) $(\mathrm{P}<0.05)$. Nearly all of nutrient intake parameters, dry matter, and protein digestibility were similar among T1, T2, and T3. The organic matter digestibility was similar for $\mathrm{T} 1$ and $\mathrm{T} 2$, both were higher than that of $\mathrm{T} 3$. The same went to ADG and feed efficiency. The highest IOFC was achieved by T2, followed by T1 and T3, respectively.

\section{DISCUSSION}

The supplementation of legume wafer increased $(\mathrm{P}<0.05)$ nutrient intake (dry matter, ether extract, crude protein, nitrogen-free extract, total digestible nutrients), organic matter digestibility, average daily gain (ADG), feed efficiency (FE), and income over feed cost (IOFC). The post-weaning Ettawa Grade goats supplemented with legume wafer were increased in dry matter intake compared to that of control. The legume wafer presumably had better palatability than the control. Argadiyasto et al. (2015) suggested that feed palatability in the form of wafer was higher than in the form of pellet. Hence, the dry matter intake increased due to increasing digestibility. Increased digestibility was probably due to better energy-synchronization in the rumen. A $13 \mathrm{~kg}$ goat requires $444 \mathrm{~g}$ dry matter/head/d assuming dry matter intake of $3.46 \%$ of the body weight. Therefore, the dry matter intake in this research exceeds the needs for basic maintenance and hence allows growth. Previous studies showed varying dry matter intake, such as 434-560 g/head/d (Suparjo et al. 2011) and 556-603 g/head/d (Lee et al., 2014). The variation was due to the difference of nutrient content in the ration, the physiological status, sex, and ingredients of the ration. Dry matter intake influences nutrient supply for both basic maintenance and growth. The nutrient intake depends on the amount of dry matter intake and the nutrient content of the feed. The post-weaning Ettawa Grade goats supplemented with legume wafer had higher crude protein intake than those without supplementation. Legume wafer seemed to fulfill the deficiency of protein of the goats. Protein intake is closely related to body weight gain, as protein is utilized for basic maintenance, production, and reproduction (Suparjo et al., 2011). 
Table 2. Nutrient intake, digestibility, average daily gain (ADG), feed efficiency, and income over feed cost (IOFC)

\begin{tabular}{|c|c|c|c|c|}
\hline \multirow{2}{*}{ Parameters } & \multicolumn{4}{|c|}{ Treatments } \\
\hline & T0 & $\mathrm{T} 1$ & $\mathrm{~T} 2$ & T3 \\
\hline \multicolumn{5}{|c|}{ Nutrient intake (g/head/d) } \\
\hline Dry matter & $661.40 \pm 57.95^{\mathrm{a}}$ & $770.72 \pm 36.62^{b}$ & $782.87 \pm 57.19^{\mathrm{b}}$ & $792.77 \pm 87.64^{b}$ \\
\hline Organic matter & $607.45 \pm 53.26^{\mathrm{a}}$ & $709.19 \pm 33.69^{b}$ & $717.76 \pm 52.43^{b}$ & $726.49 \pm 80.31^{b}$ \\
\hline Ether extract & $32.26 \pm 2.83^{a}$ & $35.32 \pm 1.70^{\mathrm{a}}$ & $36.37 \pm 2.66^{\mathrm{a}}$ & $40.65 \pm 4.49^{b}$ \\
\hline Crude protein & $85.08 \pm 7.45^{\mathrm{a}}$ & $111.07 \pm 5.17^{b}$ & $110.89 \pm 8.10^{\mathrm{b}}$ & $113.82 \pm 12.58^{b}$ \\
\hline Crude fiber & $172.61 \pm 15.12$ & $191.37 \pm 9.36$ & $193.38 \pm 14.13$ & $192.47 \pm 21.28$ \\
\hline NFE & $317.92 \pm 27.86^{\mathrm{a}}$ & $372.18 \pm 17.66^{\mathrm{b}}$ & $377.12 \pm 27.55^{\mathrm{b}}$ & $379.56 \pm 41.96^{b}$ \\
\hline TDN & $403.54 \pm 35.36^{\mathrm{a}}$ & $465.44 \pm 39.10^{\mathrm{b}}$ & $482.30 \pm 35.23^{\mathrm{b}}$ & $492.50 \pm 54.44^{\mathrm{b}}$ \\
\hline \multicolumn{5}{|l|}{ Digestibility (\%) } \\
\hline Dry matter & $77.79 \pm 4.29$ & $80.78 \pm 1.58$ & $77.35 \pm 3.76$ & $78.71 \pm 1.84$ \\
\hline Organic matter & $67.55 \pm 2.40^{\mathrm{a}}$ & $75.36 \pm 3.95^{\mathrm{b}}$ & $75.56 \pm 3.23^{b}$ & $72.47 \pm 7.20^{\mathrm{ab}}$ \\
\hline Crude protein & $60.84 \pm 0.63$ & $66.30 \pm 2.73$ & $63.71 \pm 4.83$ & $62.57 \pm 4.36$ \\
\hline IBW $(\mathrm{kg})$ & $13.26 \pm 1.08$ & $13.05 \pm 1.04$ & $12.92 \pm 1.02$ & $13.16 \pm 0.90$ \\
\hline FBW $(\mathrm{kg})$ & $16.91 \pm 1.95^{\mathrm{a}}$ & $18.78 \pm 1.05^{\mathrm{b}}$ & $19.41 \pm 1.62^{b}$ & $19.34 \pm 2.04^{\mathrm{b}}$ \\
\hline $\mathrm{ADG}(\mathrm{g} / \mathrm{d})$ & $46.99 \pm 16.62^{\mathrm{a}}$ & $72.87 \pm 5.73^{b}$ & $78.09 \pm 16.96^{\mathrm{b}}$ & $62.32 \pm 17.52^{\mathrm{ab}}$ \\
\hline FE $(\%)$ & $6.99 \pm 1.82^{\mathrm{a}}$ & $9.43 \pm 0.76^{\mathrm{b}}$ & $9.90 \pm 1.44^{\mathrm{b}}$ & $7.78 \pm 1.65^{\mathrm{ab}}$ \\
\hline IOFC (Rp/head/d) & $18,288 \pm 2,695^{\mathrm{a}}$ & $20,945 \pm 1,173^{\mathrm{ab}}$ & $21,779 \pm 2,367^{\mathrm{b}}$ & $20,910 \pm 2,639^{\mathrm{ab}}$ \\
\hline
\end{tabular}

Note: $\mathrm{T} 0=$ Basal diet/control; $\mathrm{T} 1=\mathrm{T} 0+12.12 \%$ wafer of Indigofera zollingeriana; $\mathrm{T} 2=\mathrm{T} 0+13.54 \%$ wafer of Leucaena leucocephala; $\mathrm{T} 3=\mathrm{T} 0+12.37 \%$ wafer of Calliandra calothyrsus. NNFE= Non nitrogen free extract, TDN= Total digestible nutrient, IBW= initial body weight, FBW= final body weight, $\mathrm{ADG}=$ average daily gain, $\mathrm{FE}=$ feed efficiency, $\mathrm{IOFC}=$ income over feed cost.

The post-weaning Ettawa Grade goats supplemented with legume wafer had greater organic matter digestibility than those in control, presumably because the former had higher organic matter intake than the latter. According to Bompadre et al. (2014), dry matter digestibility may vary around $75.5 \%-80.9 \%$ while organic matter digestibility around $72.2 \%-78.3 \%$. Feed digestibility is influenced by nutrient composition, type of processing, feeding level, and animal factor (McDonald et al., 2011). During wafer production, the ingredients were compressed into a compact shape, forcing the ruminants to masticate the feed longer than they normally do (Argadiyasto et al., 2015). Saliva excretion increases with longer mastication, affecting buffer mechanism in rumen. The increasing saliva helps maintaining neutral $\mathrm{pH}$ in rumen. In this condition, ruminants tend to eat more, hence increasing ADG. Additionally, feed efficiency is also improved. Supplementation of all types of legume wafer (I. zolingeriana, L. leucocephala, and C. calothyrsus) to post-weaning Ettawa Grade goats increased their ADG by $32.62 \%$ to $66.18 \%$ compared to that of control. Previous studies showed varying ADG on young goats, 81.4-109.8 g/d (Solaiman et al., 2007), 164-179 g/d (Najafi et al., 2012), 33.16-38.57 g/d (Datta et al., 2007), and 37-158 g/d (Wildeus et al., 2007). Body weight gain is influenced by several factors, i.e. total protein intake, sex, age, genetic, environmental factors, physiological status of livestock, and management.

IOFC is the profit gained by breeders after reducing feed cost from the income during the research. Supplementation of legume wafer to post-weaning Ettawa Grade goats increased the IOFC by $19.09 \%$ compared to that of control. Higher ADG, feed intake, and feed efficiency in supplemented goats may contribute to the increase. The supplementation of legume wafer in ration can to supply the requirements of post-weaning Ettawa Grade goat according to NRC, so it has resulted in improved performance compared to the control. $L$. leucocephala wafer showed the best ADG, feed efficiency, and IOFC. Good growth does not necessarily bring good profit. Nevertheless, good growth followed by good feed efficiency and minimal feed cost can maximize profit.

\section{CONCLUSION}

The addition of legumes wafer supplements in rations can increase the utility value of legumes. Wafer of L. leucocephala at $13.54 \%$ showed the best performance in post-weaning Ettawa Grade goats.

\section{ACKNOWLEDGEMENT}

The authors would like to thank the Indonesia Endowment Fund for Education, Ministry of Finance, Republic of Indonesia, for funding the research with contract No PRJ-627/LPDP.3/2016.

\section{REFERENCES}

Ali, L., L. Abdullah, P. D. M. H. Karti, M. A. Chozin, \& D. A. Astuti. 2014. Production and native value of Indigofera zollingeriana and Leucaena leucocephala in Peatland. Anim Prod. 16: 156-164.

Argadiyasto, D., Y. Retnani, \& D. Diapari. 2015. Pengolahan daun lamtoro secara fisik dengan bentuk mash, pellet dan wafer terhadap performa domba. Buletin Makanan Ternak. 102: 19-26.

Bompadre, T. F. V., O. Boaventura Neto, A. N. Mendonca, S. F. 
Souza, D. Oliveira, M. H. M. R. Fernandes, C. J. Harter, A. K. Almeida, K. T. Resende, \& I. A. M. A. Teixeira. 2014. Energy requirements in early life are similar for male and female goat kids. Asian Australas. J. Anim. Sci. 27: 17121720. https://doi.org/10.5713/ajas.2014.14140

Campbell, J. R., M. D. Kenealy, \& K. L. Campbell. 2006. Animal Sciences. 4th Edition. McGraw- Hill, New York.

Datta, C., M. K. Mondal, \& P. Biswas. 2007. Influence of dietary inorganic and organic form of copper salt on performance, plasma lipids and nutrient utilization og Black Bengal (Capra hircusI) goat kids. Anim. Feed. Sci. Technol. 135: 191-209. https://doi.org/10.1016/j.anifeedsci.2006.06.008

Imran, S. P. S. Budhi, N. Ngadiyono, \& Dahlanuddin. 2012. Pertumbuhan pedet sapi bali lepas sapih yang diberi rumput lapangan dan disuplementasi daun turi (Sesbania grandiflora). Jurnal Agrinimal 2: 55-60.

Kemenperin. 2014. Konsumsi Susu di Indonesia. http://www. kemenperin.go.id/artikel/8890/Konsumsi-Susu-Masih11,09-Liter-per-Kapita. [25 Desember 2015]

Lee, J. J., J. Soe, J. K. Jung, J. Lee, J. H. Lee, \& S. Soe. 2014. Effect of $\beta$-mannanase supplementation on growth performance, nutrient digestibility, and nitrogen utilization of Korea native goat (Capra hircus coreanae). Livestock Sci. 169: 83-87. https://doi.org/10.1016/j.livsci.2014.08.018

Mayulu, H., B. Suryanto, Sunarso, M. Christiyanto, F. I. Ballo, \& Refa'i. 2009. Feasibility of complete feed based on ammonitiated fermented rice straw utilization on the beef cattle farming. J. I. Tropic. Anim. Agri. 34: 74-78.

McDonald, P., R. A. Edwars, J. D. F. Grennhalgh, C. A. Morgan, L. A. Sinclair, \& R. G. Wilkinson. 2011. Animal Nutrition. Ed $7^{\text {th }}$. Prentice Hall, United Kingdom.

Mellado, M., C. A. Meza-Herrera, J. R. Arevalo, M. D. Santiago-Miramontes, A. Rodriguez, J. R. Luna-Orozco, \& F. G.Veliz-Deras. 2011. Relationship between litter birth weight and litter size in five goat genotypes. Anim. Prod. Sci 51:144-149. https://doi.org/10.1071/AN10112

Najafi, M. H., S. Zeinoaldini, M. Ganjkhanlou, H. Mohammadi, D. L. Hopkins, \& E. N. Ponnampalam. 2012. Performance, carcass traits, muscle fatty acid composition and meat sensory properties of male Mahabadi goat kids fed palm oil, soybean oil or fish oil. Meat Sci. 92: 848-854. https://doi. org/10.1016/j.meatsci.2012.07.012

NRC. 2007. Nutrient Requirements of Small Ruminant. National Academy Press, Washington DC.

Pond, W. G., D. C. Church, K. R. Pond, \& P. A. Schokneckt. 2005. Basic Animal Nutrition and Feeding. Matrix Publishing, Washington.

Retnani, Y., F. P. Syananta, L. Herawati, W. Widiarti, \& A. Saenab. 2010. Physical characteristic and palatability of market vegetable waste wafer for sheep. J. Anim. Prod. 12:29-33.

Retnani, Y., C. Arman, S. Said, I. G. Permana, \& A. Saenab. 2014. Wafer as feed supplement stimulates the productivity of Bali calves. APCBEE Procedia. 8: 173-177. https://doi. org/10.1016/j.apcbee.2014.03.022

Solaiman, S. G., N. K. Gurung, Q. McCrary, H. Goyal, \& W. H. McElhenney. 2009. Feeding performance and blood parameters of male goat kids fed EasiFlo ${ }^{\circledR}$ cottonseed. Small. Rum. Res. 81: 137-145. https://doi.org/10.1016/j. smallrumres.2008.12.013

Steel, R. G. D. \& J. H. Torrie. 1995. Prinsip dan Prosedur Statistik Suatu Pendekatan Biometrik. PT Gramedia Pustaka Utama, Jakarta.

Stürm, C. D., T. T. Tiemann, C. E. Lascano, M. Kreuzer, \& H. D. Hess. 2007. Nutrient composition and in vitro ruminal fermentation of tropical legume mixture with contrasing tannin contents. Anim. Feed. Sci. Technol. 138: 29-46. https:// doi.org/10.1016/j.anifeedsci.2006.11.008

Suparjo, K. G. Wiryawan, E. B. Laconi, \& D. Mangunwidjaja. 2011. Performa kambing yang diberi kulit buah kakao terfermentasi. Med. Pet. 34: 35-41. https://doi.org/10.5398/ medpet.2011.34.1.35

Wildeus, S., J. M. Luginbuhl, K. E. Turner, Y. L. Nutall, \& J. R. Collins. 2007. Growth and carcass characteristics in goat kids fed grass and alfalfa hay based diets with limited concentrate supplementation. Sheep Goat Res. J. 22: 15-19.

Zayed, M. Z., F. B. Ahmad, M. A. Zaki, W. S. Ho, \& S. L. Pang. 2014. The reduction of mimosine content in Leucaena leucocephala (petai belalang) leaves using ethyl methanesulphonate (EMS). Arch. Appl. Sci. Res. 64: 124-128. 